\title{
IMPLEMENTASI METODE BAYANI, BURHANI, TAJRIBI DAN 'IRFANI DALAM STUDI FILSAFAT PENDIDIKAN ISLAM
}

\author{
Charles Rangkuti \\ Islamic Centre Sumatera Utara J1 Willem Iskandar, Medan 20222 \\ charles_rangkuti@yahoo.co.id
}

\begin{abstract}
Abstrak: Dalam kajian epistemologi Islam, sumber segala ilmu adalah Allah. Hal ini dapat dibuktikan dengan banyaknya ayat-ayat Alquran yang menyatakan Allah sebagai pengajar atau guru. Menurut para ilmuwan Muslim, yang dikemukakan para filsuf Barat menyangkut cara-cara memperoleh pengetahuan tidak selengkap yang diinformasikan Allah dalam Alquran.Terdapat empat metode ilmiah yang diakui dalam dunia intelektual Islam, yaitu metode bayani (tafsir/takwil), metode burhani (logis), metode tajribi (observasi dan experiment) dan metode irfani (intuisi).Metode bayanidigunakanoleh kaum mufasir untuk menggali ilmu dalam Alquran dan hadis, metode burhaniditerapkan kaum filsuf untuk memahami objek-objek non-fisik, metode tajribi diterapkan saintis untuk mengkaji objekobjek fisik dan metode irfani diterapkan oleh sufi untuk menyaksikan objekobjek non-fisik.Metode bayani adalah metode yang menggunakan teks dalam memperoleh ilmu pengetahuan.Pertama, Epistemologi keilmuan dalam Islam jauh lebih lengkap daripada epistemologi dalam keilmuan Barat.Kedua, pendekatanpendekatan keilmuaan yang digagas dan mulai dipraktekkan umat Islam belakangan ini seperti integrasi keilmuaan, integrasi-interkoneksi, pohon ilmu, transdisipliner merupakan kelanjutan dari sejarah epistemologi keilmuan di zaman keemasan Islam. Ketiga, terjadi ketimpangan umat Islam dalam menggunakan keempat epistemologi keislaman dalam menyikapi ilmu.Sehingga umat Islam sangat kaya dengan teks-teks keagamaan namun tertinggal dalam bidang ilmu-ilmu alam, sosial dan humaniora kontemporer.
\end{abstract}

Kata Kunci: Implementasi, Filsafat, Pendidikan Islam

\section{Pendahuluan}

Dalam kajian epistemologi Islam, sumber segala ilmu adalah Allah.Hal ini dapat dibuktikan dengan banyaknya ayat-ayat Alquranyang menyatakan Allah sebagai pengajar atau guru. ${ }^{1}$ Menurut para ilmuwan Muslim,yang dikemukakan para filsuf Barat menyangkut cara-cara memperoleh pengetahuan tidak selengkap yangdiinformasikan Allah dalam Alquran. ${ }^{2}$ Alquran memperkenalkan cara-cara meraih ilmu yang sangat komprehensif, seperti menarik pelajaran dari

${ }^{1}$ Q. S. al-Baqarah /2: 31, 32, 239, 251, 282. Q. S. ar-Rohman/ $55: 2$, 4. Q. S. al-'Alaq /96: 4-5. Q. S. al-Ma'idah/ 5: 4, 110. Q. S.Yusuf/12: 6, 21, 37, 68, 101. Q. S. an-Nisa'/ 4: 113. Q. S. al-Kahfi /18: 65. Q. S. al-Anbiya'/21: 80. Q. S. Yasin /69. Q. S at-Tahrim / 53: 5. Q. S. alHujurat/ 49: 16. Q. S. Alu Imran/3: 48. Q. S. al-An'am /6 : 91.

${ }^{2}$ Penelusuran ayat-ayat Alquran dalam makalah ini merujuk ke buku Muhammad Fu'ad 'Abd al-Baqi, Al-Mu'zam al-Mufahras li al-Fazh al-Qur'an al-Karim (Kairo: Dar al-Hadis, 2007). 
perjalanan,melakukan pandangan kritis terhadap alam dan fenomenanya, memperhatikan dan mengambil pelajaran dari sejarah manusia, mengamati manusia.Salah satu keistimewaan epistemologi Alquran adalah informasinya tentang objek yang tidak tampak betapapun tajamnya mata kepala atau pikiran dalam menganalisa objek tersebut. ${ }^{3}$

Mulyadhi Kartanegara dalam Al Rasyidin dan Ja'far menjelaskan bahwa di Barat hanya ada satu metode ilmiah yang diakui dalam menyibak ilmu pengetahuan, yaitu metode tajribi (observasi atau experiment), sedangkan dalam epistemologi Islam, selain metode tajribi masih ada tiga metode lagi yang tidak dikenal dan dipraktekkan oleh dunia intelektual Barat. Dengan demikian ada empat metode ilmiah yang diakui dalam dunia intelektual Islam, yaitu metode bayani (tafsir/takwil), metode burhani (logis), metode tajribi (observasi dan experiment) dan metode irfani (intuisi).Metode bayanidigunakanoleh kaum mufasir untuk menggali ilmu dalam Alquran dan hadis, metode burhaniditerapkan kaum filsuf untuk memahami objek-objek non-fisik, metode tajribi diterapkan saintis untuk mengkaji objek-objek fisik dan metode irfani diterapkan oleh sufi untuk menyaksikan objek-objek non-fisik. ${ }^{4}$

\section{Pembahasan}

Sejak awal,epistemologi Islam mengakui dua jenis ilmu sekaligus, yaitu ilmu agama dan ilmu alam.Kedua jenis ilmu itu diakui dan dikategorikan Islam sebagai pengetahuan ilmiah dan dikembangkan dengan metode yang ilmiah.Karena lengkapnya sumber ilmu pengetahuan dalam Islam, sehingga ilmu dalam Islam tidak membedakan - sebagaimana yang terjadi di Barat- antara science dan knowledge.Istilah science disematkan ilmuwan Barat kepada ilmu yang bersifat fisik dan empiris, sedangkan istilah knowledge disematkan Barat untuk ilmu yang bersifat nonfisik seperti konsep mental dan metafsika.Agaknya kecelakaan istilah ini berimplikasi juga terhadap Bahasa Indonesia, hal ini dibuktikan dengan diterjemahkannya kata science dengan ilmu pengetahuan, sedangkan knowledge diterjemahkan dengan pengetahuan.Pemikiran epistemologi Barat ini

\footnotetext{
${ }^{3}$ M. Quraish Shihab, Membumikan Alquran jilid 2, (Jakarta: Lentera Hati, 2010), h. 348.

${ }^{4}$ Al Rasyidin \& Ja'far, Filsafat ilmu dalam tradisi Islam, (Medan: Perdana Publishing, 2015), h. 93
} 
mengimplikasikan bahwa yang diakui sebagai ilmu hanyalah hal-hal yang bersifat empiris saja, sementara hal-hal yang tidak terjangkau panca indra tidak mereka akui sebagi ilmu. Sebenarnya, fenomena pembagian ilmu seperti ini baru terjadi di abad modern, yaitu sejak masuknya paham positivisme, ${ }^{5}$ maka sejak masuknya paham ini, yang diakui sebagai ilmu hanya objek yang terukur secara empiris dan disebut dengan scientific knowledge atau science. Sedangkan sampai pada abad pertengahan istilah knowledge masih mencakup semua jenis ilmu pengetahuan. ${ }^{6}$

\section{Metode Bayani}

Metode bayani adalah metode yang menggunakan teks dalam memperoleh ilmu pengetahuan. Metode ini sangat mengandalkan teks dalam mencari kebenaran. Apa pun fenomena yang terjadi dalam realitas dunia akan dicari bimbingannya dalm teks. Dalam konteks pemikiran Islam, metode bayani adalah metode tafsir atau takwil yang diterapkan oleh para mufasir dalam menggali ilmu dari Alquran dan hadis. ${ }^{7}$ Dengan sedikit perbedaan, dalam pandangan al-Jabiry, corak epistemologibayani didukung oleh pola pikir fikih dan kalam. ${ }^{8}$

Dalam epistemologi Islam, tradisi menggali makna teks atau apa yang disebut dengan tafsir merupakan salah satu metode ilmiah yang diakui sebagai sumber ilmu. Melalui metode tafsir ini sang mufasir menggali makna yang tersembunyi di balik teks Tuhan yang sesuai dengan kecenderungan sang mufasir. Itulah sebabnya dalam kitab-kitab tafsir ditemukan informasi yang beragam tentang dasar-dasar ilmu.Seperti pembahasan mufasir tentang dasar-dasar religious science, natural science, social science dan humaniora science. ${ }^{9}$

Selain interaksi dengan teks wahyu, dari aspek ilmu-ilmu keislaman, ditemukan juga metode ilmiah -dalam konteks berinteraksi dengan teks- yang lain yang patut diketahui untuk diimplementasikan oleh ilmuwan Muslim dalam aktivitasnya ketika menggeluti ilmu sesuai bidangnya masing-masing. Misalnya, ilmu ushul al-Fiqh, takhrij al-Hadis dan al-Jarh waat-Ta'dil. Dengan ilmu ushul

${ }^{5}$ Amsal Bakhtiar, Filsafat Ilmu, (Jakarta: Raja Grafindo, Cet 12, 2013), h. 64.

${ }^{6}$ Adian Husaini, et. al, Filsafat Ilmu perspektif Barat dan Islam, (Depok: Gema Insani, Cet 5, 2014), h. 59-60.

${ }^{7}$ Al Rasyidin,, Filsafat, h. 93.

8 M. Amin Abdullah, Islamic Studies di perguruan tinggi: Pendekatan integratifinterkonektif, (Yogyakarta: Pustaka Pelajar, Cet 3, 2012), h. 202.

${ }^{9}$ Bandingkan klasifikasi ilmu tersebut dengan Ahmad Tafsir, Filsafat Ilmu: Mengurai Ontologi, Epistemologi dan Aksiologi Pengetahuan, (Bandung: Remaja Rosdakarya, 2015, Cet 8), h. 25-27. 
al-Fiqh seorang pakar hukum Islam dapat memperoleh pedoman dalam mengeluarkan hukum Islam, dan dengan ilmu takhrij al-Hadis seorang pakar Islam mendapat bimbingan ketika mengeluarkan statemen tentang ilmu-ilmu keislaman.

Di sisi lain, yang membidangi rumpun ilmu lain selain agama juga diharuskanuntuk mengetahui dan berinteraksi dengan teks dalam Islam. Karena dengan interaksi para ilmuwan Muslim terhadap teks maka ilmu mereka akan tetap terbimbing dan terarah dalam bingkai ajaran Islam. ${ }^{10}$ Metode nalar bayani ini dapat dilacak akar perintahnya dalam Alquran. ${ }^{11}$

\section{Metode Burhani}

Metode burhani adalah metode yang menggunakan akal untuk memperoleh ilmu pengetahuan.Metode ini sangat mengandalkan akal dalam mencari ilmu pengetahuan. Dalam pandangan penganut epistemologi ini, akal memilkii kemampuan untuk menemukan berbagai macam ilmu pengetahuan, bahkan -kata mereka- akal juga bisa diufungsikan untuk menemukan kebenaran dalam bidang apa pun, termasuk kebenaran dalam agama.

Dalam sejarah Islam, metode burhani dijadikan kaum rasionalis yang terdiri dari filsuf dan teolog sebagai metode yang digunakan untuk menemukan teori-teori yang rasional. Dalam bidang filsafat paripatetik yang menggunakan metode ini lahir nama-nama besar seperti al-Kindi, al-Farabi, Ibn Sina dan Ibnu Rusyd. Dari kalangan teolog yang menggunakan metode ini lahir aliran Muktazilah dan Syiah, dan dengan menngunakan metode dari kalangan fukaha lahir mazhab yang sangat rasional, yaitu mazhab Hanafi. Tidak ketinggalan pula dari kaum mufasir yang beraliran dirayah dengan menggunakan metode burhani ini, sehingga lahirlah tafsir bi al-Ra' $y i .^{12}$

Dalam dunia filsafat,baik filsafat Islam maupun filsafat Barat istilah yang sering digunakan untuk metode burhani adalah rasionalisme, yaitu aliran yang menyatakan bahwa akal adalah dasar kepastian, sekalipun informasi akal itu belumdidukung oleh fakta empiris. Tokoh-tokoh aliran rasionalis ini adalah Rene

\footnotetext{
${ }^{10} \mathrm{Al}$ Rasyidin, Filsafat, h. 102.

${ }^{11}$ Q. S an-Nahl/ 16: 44.

${ }^{12}$ Lihat uraian panjang lebar tentang para Penulis dan kitab-kitab tafsir yang beraliran rasional dalam Muhammad Husain adz-Zahabi, Al-Tafsir wa al-Mufassirun, Jilid I (Kairo: Dar alHadis, 2005), h. 247-400.
} 
Descartes (1596-1650, Baruch Spinoza (1632 -1677) dan Gottried Leibniz (1646 $-1716){ }^{13}$

Sebenarnya metode rasional ini adalah ajaran yang bersumber dari ajaran Alquran.Hal ini dapat dibuktikan dengan melihat begitu banyak jumlah ayat Alquran yang memerintahkan untuk berfikir, menalar, menganalisa dan lainlain. $^{14}$

\section{Metode Tajribi}

Metode tajribi adalah metode yang menggunakan pengamatan alat indrauntuk memperoleh ilmu pengetahuan. Metode ini sangat mengandalkan indradalam menelaah dan meneliti objek material yang merupakan sumber ilmu pengetahuan. Para ilmuwan klasik telah menerapkan metode ini dalam pergumulan mereka dengan ilmu pengetahuan, sehingga mereka menguasai ilmuilmu yang rasional seperti metafisika, matematika, kedokteran, psikologi, fisika, etika, ekonomi dan politik. Yang lebih menakjubkan lagi, selain menguasai ilmuilmu yang rasional mereka juga mendalami metode intuitif di penghujung kehidupan mereka, seperti yang terlihat dalam sosok ilmuwan ensiklopedis seperti Ibnu Sina. ${ }^{15}$

Dalam konteks modern, sebenarnya pendekatan integratif-interkonektif, pohon ilmu dan transdisipliner bukanlah barang baru dalam tradisi keilmuan Islam. ${ }^{16}$ Pendekatan-pendekatan (approach) tersebut telah dipraktekkan dan dikembangkan di zaman keemasan Islam. Dua atau tiga abad belakangan ini, metode tajribi ini telah dikembangkan ilmuwan Barat modern yang disebut dengan scientific method. Metode ini digunakan dalam mengembangkan ilmuilmu alam dan ilmu-ilmu sosial. Metode ini penggabungan antara metode empirisme dan rasionalisme serta penggabungan antara cara berfikir deduktif dan induktif. $^{17}$

${ }^{13}$ Al Rasyidin, Filsafat, h. 106.

${ }^{14}$ Q. S. al-Baqarah/2: 44, 73, 76, 242. Q. S. alu-Imran/ 3: 65, 118. Q. S al-‘An’am/6: 50. Q. S al-A'raf/ 7:174.

15 Lihat analisa menarik dari Abuddin Nata tentang para ilmuawan Muslim yang ensiklopedik itu dalam bukunya, Sejarah sosial intelektual Islam dan institusi pendidikannya, (Jakarta: RajaGrafindo Persada, 2012), h. 132-133.

${ }^{16}$ Lebih jauh lihat Humaidi, Paradigma Sains integratif Al-Farabi: Pendasaran Filosofis bagi Relasi Sains, Filsafat dan Agama, (Jakarta: Sadra Press, 2015), h. 126-135.

${ }^{17}$ Al Rasyidin, Filsafat, h. 102. 
Cara berfikir ilmiah yang belakangan dikembangkan ilmuwan Barat itu memilki langkah-langkah yang ilmiah pula dalam prosedur dan pelaksanaannya. Langkah-langkah ilmiah itu dapat diuraikan sebagai berikut: (1) Perumusan masalah, yaitu pertanyaan mengenai objek empiris yang batas-batasnya jelas dan faktor-fakor yang terkait dengannya dapat didefinisikan; (2) Penyusunan kerangka berfikir; (3) Perumusan hipotesis, yaitu jawaban sementara terhadap pertanyaan yang diajukan; (4) Pengujian hipotesis, yaitu pengumpulan fakta yang berkaitan dengan hipotesis; (5) Penarikan kesimpulan, yaitu penilaian yang membuktikan apakah hipotesis itu diterima atau dtolak. ${ }^{18}$

Kalau diamati dengan jeli, metode ini sangat didorong Alquran untuk dikembangkan dalam memahami alam material. Dorongan Alquran itu dibuktikan dengan begitu banyak jumlah ayat Alquran yang memerintahkan untuk melakukan observasi dan experiment dalam berbagai objek yang bersifat material. ${ }^{19}$

\section{Metode 'Irfani}

Metode irfani adalah metode yang menggunakan pengalaman dalam memperoleh ilmu pengetahuan. Metode ini menggunakan pengalaman atau penyaksian secara langsung dalam mengungkap pengetahuan yang diperoleh lewat penyinaran hakikat Tuhan kepada manusia. Menurut filsafat, metode 'irfani ini lebih dikenal dengan istilah intuisi.Sebagian filosof membagi intuisi pada tiga macam. Pertama, berdasarkan pengalaman indra, seperti pengetahuan tentang warna dan aroma suatu objek. Kedua, berdasarkan nalar dan bersifak aksioma, seperti si A adalah A, si A bukan B atau angka 10 lebih banyak dari angka 9. Ketiga, ide cemerlang yang muncul secara tiba-tiba. Seperti yang dialami ahli matematika Yunani Archimedes (212-287 M) ketika kebingungan untuk membuktikan apakah mahkota Raja Hieron adalah benar-benar emas murni atau telah dicampur oleh pandai emas yang membuatnya dengan bahan selain emas? Namun yang menakjubkan, justru jawaban dari kebingungan itu ditemukan bukan ketika berfikir, akan tetapi jawaban itu “diinformasikan” Tuhan ketika berenang.

\footnotetext{
${ }^{18}$ Jujun S. Suriasumantri, Filsafat Ilmu: Sebuah pengantar populer, (Jakarta: Pustaka Sinar Harapan, Cet 24, 2013), h. 127-128.

${ }^{19}$ Q. S al-Baqarah/ 2: 164, Q. S Yunus/ 10: 101, Q. S al-'Ankabut/29: 30, Q. S al-Rum/ 30: 42, Q. S al-Ghasyiah/ 88: 17-20, Q. S Fushshilat/ 41: 53.
} 
Dari pengalaman itu, kemudian pakar ini menemukan ide tentang apa yang kemudian dinamai dengan berat jenis. ${ }^{20}$

Pengalaman serupa juga pernah terjadi kepada Issac Newton (1642-1727 M). Pakar ini menemukan gaya gravitasi setelah melihat apel yang terjatuh tidak jauh dari tempat ia duduk. Namun, hal yang perlu dicatat dalam konteks intuisi jenis ketiga ini bahwa ide cemerlang itu hadir setelah didahului pemikiran yang mendalam dan melelahkan menyangkut suatu objek, dan ketika sang pemikir telah lelah, lalu beristirahat, tiba-tiba muncul jawaban yang selama ini dicari dengan penuh kelelahan. Dua contoh yang dekemukakan di atas adalah hal yang terjadi kepada pemikir dan peneliti yang telah berfikir dalam mencari ilmu dan hakikat sesuatu secara mendalam. ${ }^{21}$

Menurut pakar tafsir M. Quraish Shihab intuisi ini bisa saja terjadi di alam nyata, tetapi bisa juga terjadi di alam tidur. Mimpi yang dialami manusia sering kali dialami manusia dalam bentuk tersirat, kemudian makna dari mimpi itu baru disadari ketika kebenarannya terbukti di alam nyata. Berulangnya sebuah mimpi yang kemudian terbukti di alam nyata bisa menghasilkan penafsiran yang sama untuk mimpi itu. Seperti, menafsirkan mimpi gigi tercabut atau rontok sebagai informasi tentang kematian keluarga. ${ }^{22}$ Begitu juga yang terjadi kepada Umar bin Khaththab yang bermimipi dipatuk seekor ayam jantan sebanyak dua kali. kemudian beliau tafsirkan mimpi itu bahwa beliau akan dibunuh seorang nonArab, ternyata mimpi itu benar-benar terjadi di alam nyata. ${ }^{23}$ Ibnu sina (980-1037 M) juga sangat sering mendapat jawaban melalui mimpi menyangkut pertanyaanpertanyaan yang timbul dalam pikirannya di alam nyata. ${ }^{24}$

Sebenarnya, metode ilmu jenis intuisi ini sudah diinformasikan Allah dalam wahyu pertama yang diterima Nabi Muhhammad. ${ }^{25}$ Di sisi lain, Alquran juga menginformasikan bahwa ilmu jenis ini juga telah diberikan kepada seorang

${ }^{20}$ M. Quraish Shihab, Menabur Pesan Ilahi: Al-Qur'an dan Dinamika Kehidupan Masyarakat, (Jakarta: Lentera Hati, 2006), h. 140-143.

${ }^{21}$ Shihab, Menabur, h. 141-142.

${ }^{22}$ M. Qurasih Shihab, Dia di mana-mana: "Tangan" Tuhan di balik setiap fenomena, (Jakarta: Lentera Hati, Cet 6, 2008), h. 192.

${ }^{23}$ Shihab, Menabur, h. 142.

${ }^{24}$ Shihab, Dia, h. 192.

${ }^{25}$ Q. S. al-'Alaq/ $96: 5$. 
Nabi yang menjadi guru seorang Nabi dan Rasul. ${ }^{26}$ Dengan demikian, perolehan ilmu jenis intuisi ini adalah metode ilmiah yang diakui dalam ajaran Islam sekalipun diingkari dalam metode ilmiah Barat.

\section{Beberapa Catatan Penting}

Menurut mantan Rektor dan Guru besar Islamic Studies UIN Sunan Kalijaga Yogykarata Prof Dr M. Amin Abdullah bahwa corak pemikiran keislaman model bayani(mengandalkan teks) itu sangat mendominasi dan bersifat hegemonik dalam tradisi dan pengajaran keilmuaan agama Islam baik di IAIN, STAIN, PTU dan terlebih-lebih lagi di Pesantren-pesantren. Karena sifatnya yang mendominasi dan hegemonik sehingga sulit berdialog dengan tradisi epistemologi irfani dan burhani apalagi tajribi. ${ }^{27}$ Penyebab kurang disukainya corak pemikiran irfani oleh corak pemikiran bayani paling tidak sebabnya ada tiga. Pertama, karena bercampuraduknya -atau bahkan- dikaburkannya tradisi berfikir keilmuanirfanidengan kelompok-kelompok atau oragnisasi-organisasi tarekat dengan sathahat-sathahat yang mereka ciptakan. Kedua, karena tradisi nalar bayani kurang memahami struktur fundamental epistemologi dan pola pikir nalar 'irfani. Ketiga, karena nalar bayani tidak memahami nilai manfaat yang terdapat dalam tradisi nalar irfani.

Sebagai akibatnya, pola pemikiran Islam model bayani menjadi kaku dan rigid. Otoritas teks -yang merupakan sumber utama- dalam epistemologi nalar bayani yang dibakukan dalam kaidah-kaidah lebih diunggulkan dan didahulukan daripada sumber keilmuan yang lain seperti alam, akal dan intuisi.Akibat selanjutnya dari dominasi nalar bayani ini adalah menjadikan sistem epistemologi keagamaan Islam kurang respek dan peduli terhadap isu-isu kontemporer yang dialami umat Islam. ${ }^{28}$ Karena sulitnya lepas dari bayang-bayang dominasi teks sampai-sampai setiap problem yang ada selalu dicarikan solusinya dalam teks.

Kelemahan yang paling menonjol dari tradisi nalar epistemologi bayani ini adalah ketika berdialog dan berhadapan dengan teks-teks keagamaan yang

\footnotetext{
${ }^{26}$ Q. S al-Kahfi/ 18: 65.

${ }^{27}$ Sepanjang jangkauan bacaan Penulis terhadap karya-karya M. Amin Abdullah, Penulis tidak menemukan Guru Besar ini membahas metode tajribi.

${ }^{28}$ Lihat Hassan Hanafi, Studi Filsafat 1: Pembacaan Atas Tradisi Islam Kontemporer, (Yogyakarta: LKiS, 2015), h. 194-195.Penerjemah tidak menyebutkan judul asli dari Buku ini.
} 
dimiliki oleh komunitas atau masyarakat yang beragama lain. Karena mau tidak mau, nalar epistemilogi bayani ketika didialogkan dengan teks komunitas atau masyarakat yang beragama lain akan mengambil sikap mental yang dogmatik atau mengambil sikap sesuai dengan semboyan "right or wrong is my country”. Sikap ini bisa muncul karena fungsi dan peran akal tidak lain hanyalah digunakan dan digiring untuk mengukuhkan, mendukung bahkan membenarkan teks. Corak epistemologi bayani ini tidak akan memperhitungkan apakah implementasi panduan teks masih seorisinil dan seotentik lafal teks. Karena mengaitkan antara teks dan realitas bukanlah ciri khas pola pikir epistemologi nalar bayani.

Di samping itu, nalar epistemologi bayani selalu mencurigai akal pikiran, karena dengan memberikan otoritas lebih kepada akal bisa saja akal menjauhi kebenaran yang tekstual.Sampai-sampai nalar epistemilogi ini pada kesimpulan bahwa wilayah kerja akal perlu dibatasi perannya dan dialihklan menjadi pengekang hawa nafsu, bukannya diarahkan untuk mencari hukum sebab akibat melalui analisis keilmuan yang pasti. Pola pikir bersatunya teks dan akal ternyata memunculkan kekakuan-kakakuan, bahkan tidak jarang konflik dan kekerasan yang terjadi bersumber dari pola pikir ini. ${ }^{29}$ Menurut hemat penulis, sampai dengan detik ini pola pikir bayani ini masih tetap mendominasi dalam pemikiran umat Islam. Hal ini ditandai dengan setiap ada masalah sosial umat Islam langsung membuka kitab suci dan mencarikan solusinya secara tekstual. Dan hal ini juga yang menyebabkan adanya ketegangan antar umat beragama. Yang lebih parah lagi, kalau pola pikir bayani ini ditunggangi politik dan kepentingan pihakpihak tertentu. ${ }^{30}$

Menurut Doktor jebolan Middle East Technical University (METU) itu diperlukan kajian-kajian yang baru dan serius tentang kerangka berfikir epistemologi irfani supaya pola pikir ini praktis dan fungsional dalam kehidupan masyarakat luas. Karena agama yang tidak memilki pola pikir irfani akan sangat sulit berinteraksi dengan realitas pluralitas keagamaan umat manusia. Kesulitan interaksi itu tidak hanya terjadi secara internal keagamaan tetapi bisa juga terjadi secara eksternal. Walaupun umat manusia tetap sah untuk bersekat-sekat dalam berbagai identitas lewat tradisi formal, namun dengan pola pikir nalar

\footnotetext{
${ }^{29}$ Abdullah, Islamic, h. 202-206.

${ }^{30}$ Fenomena Q. S al-Maidah/ 5: 51 berangkali bisa diangkat sebagai contoh.
} 
epistemologi 'irfani ini mereka dapat mendekat tanpa melebur kepribadian apalagi akidah masing-masing. Itulah sebabnya, dalam tradisi nalar epistemologi 'irfani, istilah 'arif lebih diutamakan daripada istilah 'alim. Karean istilah 'alim lebih menonjolkan nalar bayani, sedangkan istilah 'arif lebih menonjolkan nalar 'irfani.Secara sosiologis, budaya dan masyarakat Indonesia lebih mengharagai dan menghormati orang yang 'arif daripada orang yang 'alim dalam pergaulan masyarakat sehari-hari. Dari uraian di atas sangat kentara sekali bahwa nalar epistemologi 'irfani sangat subur dan mudah diterima masyarakat pada umumnya.

Menurut guru besar itu, Kalau merujuk ke pemikiran tokoh filosof Muslim klasik akan ditemukan bahwa epistemologi burhani telah disebut-sebut oleh Ibnu Rusyd. Namun sangat disayangkan, karena hegemoni epistemologi bayani menjadikan nalar epistemologi burhani, irfanidan tajribi tersingkir dari dari panggung sejarah pemikiran keislaman. ${ }^{31}$ Padahal nalar burhanidan tajribi sangat penting bagi kemajuan Islam karena pendekatannya yang selalu mengandalkan realitas, baik realitas alam, realitas sosial, realitas humanitas maupun realitas keagamaan. Karena dengan pendekatan yang serba realitas ini maka ilmu yang dilahirkan nalar burhani dan tajribi adalah ilmu yang dikonsep, disusun dan disistematisasikan lewat premis-premis logika. Kemudian premis-premis logika tersebut disusun lewat kerjasama antara proses abstraksi, penggunaan indra yang sahih atau dengan mendampingi indra tersebut dengan alat-alat laboratorium, proses penelitian lapangan. Tapi yang lebih perlu diperhatikan, peran akal sangat penting di sini, karena fungsi akal dalam nalar burhanidan tajribi ini adalah untuk mencari hukum sebab-akibat. Dalam konteks mencari hukum sebab akibat yang terjadi pada peristiwa-peristiwa alam, sosial, kemanusiaan dan keagamaan, akal pikiran tidak membutuhkan teks-teks keagamaan. Bahkan dalam memahami dan memetakan keempat peristiwa tersebut akan lebih memadai apabila digunakan pendekatan-pendekatan ilmu sosiologi, antropologi dan sejarah. ${ }^{32}$

Tolok ukur kebenaran dalam nalar burhani dan tajribi ini sangat rasional, yakni kesesuaian antara rumus-rumus yang diciptakan oleh akal manusia dengan hukum-hukum alam (korespondensi), keruntutan dan ketepatan berpikir logis (koherensi) dan upaya secara bersinambung untuk memperbaiki dan

\footnotetext{
${ }^{31}$ Abdullah, Islamic, h. 212.

${ }^{32}$ Ibid, h. 214.
} 
menyempurnakan temuan-temuan, rumus-rumus dan teori-teori yang telah dibangun dan disistematisasikan oleh jerih payah akal manusia (pragmatik). ${ }^{33}$

Mengingat pentingnya peranan nalar epistemilogi bayani, tajribi dan ‘irfani dalam pemikiran keislaman, Itulah sebabnya nalar epistemologi burhani, tajribi dan 'irfani harus direkonstruksi ulang dengan memberikan pemaknaanpemaknaan baru untuk mendampingi nalar epistemologi bayani yang selama ini telah mendominasi. Menurut hemat penulis, akibat hegemoni dan dominasi nalar bayani yang berjalan selama ini maka pemikiran keislaman lebih banyak menimbun teks daripada aksi. Hal ini terbukti dengan banyaknya kitab-kitab yang diproduksi ulama dalam bidang ilmu-ilmu keagamaan tapi sangat minim dalam bidang ilmu-ilmu kealaman dan sosial. Agaknya ini juga penyebab mundurnya umat Islam dari zaman pertengahan, karena pemikirnya lebih banyak menimbun materi keilmuan yang berulang-ulang seperti tergambar dalam buku-buku yang berbentuk matan, syarah dan hasyiah.

Sebenarnya ketiga - penulis tambahkan dengan nalar epistemologi tajribikluster sistem epistemologi ilmu-ilmu agama ini masih berada dalam satu rumpun yang sama. Tetapi kesamaan itu hanya ada dalam teori, karena dalam praktiknya seluruh kluster keilmuan itu sangat sering saling kafir-mengkafirkan, murtadmemurtadkan dan sekuler-mensekulerkan. ${ }^{34}$

\section{Kesimpulan}

Berdasarkan uraian dan anlisis sebagaimana yang disebutkan di atas dapat ditarik beberapa kesimpulan sebagai berikut; Pertama, Epistemologi keilmuan dalam Islam jauh lebih lengkap daripada epistemologi dalam keilmuan Barat. Kedua, pendekatan-pendekatan keilmuaan yang digagas dan mulai dipraktekkan umat Islam belakangan ini seperti integrasi keilmuaan, integrasi-interkoneksi, pohon ilmu, transdisipliner merupakan kelanjutan dari sejarah epistemologi keilmuan di zaman keemasan Islam. Ketiga, terjadi ketimpangan umat Islam dalam menggunakan keempat epistemologi keislaman dalam menyikapi ilmu. Sehingga umat Islam sangat kaya dengan teks-teks keagamaan namun tertinggal dalam bidang ilmu-ilmu alam, sosial dan humaniora kontemporer.

\footnotetext{
${ }^{33}$ Abdullah, Islamic, h. 386. Lihat juga Suriasumantri, Filsafat, h. 57.

${ }^{34}$ Abdullah, Islamic, h, 202-203.
} 


\section{Pustaka Acuan}

Alquran al-Karim

'Abd al-Baqi, Muhammad Fu'ad, Al-Mu'zam al-Mufahras li al-Fazh al-Qur'an al-Karim, Kairo: Dar al-Hadis, 2007.

Abdullah, M. Amin, Islamic Studies di perguruan tinggi: Pendekatan integratifinterkonektif, Yogyakarta: Pustaka Pelajar, Cet 3, 2012.

Al Rasyidin \& Ja'far, Filsafat ilmu dalam tradisi Islam, Medan: Perdana Publishing, 2015.

Az-Zahabi, Muhammad Husain, Al-Tafsir waal-Mufassirun, Kairo: Dar al-Hadis, 2005.

Bakhtiar, Amsal, Filsafat Ilmu, Jakarta: Raja Grafindo, Cet 12, 2013.

Hanafi, Hassan, Studi Filsafat 1: Pembacaan Atas Tradisi Islam Kontemporer, Yogyakarta: LKiS, 2015.

Humaidi, Paradigma Sains integratif Al-Farabi: Pendasaran Filosofis bagi Relasi Sains, Filsafat dan Agama, Jakarta: Sadra Press, 2015.

Husaini, Adian, et. al, Filsafat Ilmu perspektif Barat dan Islam, Depok: Gema Insani, Cet 5, 2014.

Nata, Abuddin, Sejarah sosial intelektual Islam dan institusi pendidikannya,Jakarta: RajaGrafindo Persada, 2012.

Suriasumantri, Jujun S., Filsafat Ilmu: Sebuah pengantar populer, Jakarta: Pustaka Sinar Harapan, Cet 24,2013.

Shihab, M. Quraish, Membumikan Alquran jilid 2, Jakarta: Lentera Hati, 2010.

Shihab, M. Quraish, Dia dimana-mana: "Tangan" Tuhan di balik setiap fenomena, Jakarta: Lentera Hati, Cet 6, 2008.

Shihab, M. Quraish, Menabur pesan Ilahi; Alquran dan dinamika kehidupan Masyarakat, Jakarta: Lentera Hati, 2006.

Tafsir, Ahmad, Filsafat Ilmu: Mengurai Ontologi, Epistemologi dan Aksiologi Pengetahuan, Bandung: Remaja Rosdakarya, 2015. 